\title{
REE-bearing epidote from Sanbagawa pelitic schists, central Shikoku, Japan
}

\author{
Chihiro SaKai ${ }^{1}$, Toshio Higashino ${ }^{2}$ and Masaki Enami ${ }^{3}$ \\ Department of Geology and Mineralogy, Faculty of Science, Kyoto University, Kyoto $606^{1}$, \\ Hakusan Nature Conservation Center, Yoshinodani-mura, Ishikawa $920-23^{2}$ and \\ Department of Earth Science, Faculty of Science, Nagoya University, Nagoya $464^{3}$, Japan
}

(Received August 27, 1983: Accepted January 16, 1984)

Epidote, which contains significant amounts of rare earth elements and thorium, and allanite occur in the Sanbagawa pelitic schists of central Shikoku at all the metamorphic grades. Petrographical and chemical studies suggest a metamorphic origin of the REE-bearing epidote and a detrital origin of the allanite. The detrital allanite is the major source of REE and Th in the metamorphic epidote.

\section{INTRODUCTION}

Allanite is a common accessory mineral in the pelitic and psammitic schists of the Sanbagawa metamorphic terrain (SUZUKI, 1930; KoIDE, 1937; HoRIKosHI, 1938; HIDE, 1961; Higashino, 1975). Recently, it has been found that some epidotes in Sanbagawa pelitic schists of central Shikoku also contain significant amounts of REE (rare earth elements), totaling up to 15 wt. per cent as oxides and of $\mathrm{ThO}_{2}$ up to $1.0 \mathrm{wt}$. per cent. In central Shikoku, REE and Th-bearing epidotes are always associated with REE and Th-free epidotes or zoisite, and are sometimes accompanied by allanite. Petrographical and chemical studies suggest a metamorphic origin of REE-bearing epidote*, and a detrital origin of the allanite. This study is aimed to understand the behavior of REE during the Sanbagawa metamorphism and regional metamorphism, on the basis of petrographical and chemical studies of REE-bearing minerals. In this paper, the mode of occurrence and chemistry of the REE-bearing epidote and allanite will be described, and then their geneses will be discussed.

\section{SAMPle Locality, Mode of OCCURRENCE AND PETROGRaPHY}

Figure 1 shows the mineral zones of the Sanbagawa metamorphic terrain in central Shikoku, and the route along which the samples were collected. The grade of metamorphism increases from the chlorite through garnet and albite-biotite to oligoclase-biotite zones with reference to the pelitic schists (BANNO, 1964; HigASHINO, 1975; BANNO et al., 1978; ENAMI, 1981, 1982, 1983). The pelitic schists always contain quartz, albite, muscovite, epidote and graphite (only poorly crystallized in the chlorite zone (ITAYA, 1981)), associated with various combinations of chlorite, garnet, biotite, oligoclase and hornblende.

Two hundred and fifty one samples of pelitic schists from various mineral zones were examined under the microscope. REE-bearing epidote is very fine-grained, very low in modal amount, and colorless, and hence optically it is not distinguished from REE-free epidote and

* DEER et al. (1962) called all cerium epidotes allanites (the amount of $\mathrm{Ce}_{2} \mathrm{O}_{3}$ is more than 7.44 wt \% in their table). The epidotes under consideration are herein termed REE-bearing epidotes, because the amount of $\mathrm{REE}_{2} \mathrm{O}_{3}+\mathrm{ThO}_{2}$ of the epidotes is less than that of allanites reported by HASEGAWA (1960) and DEER et al. (1962). 

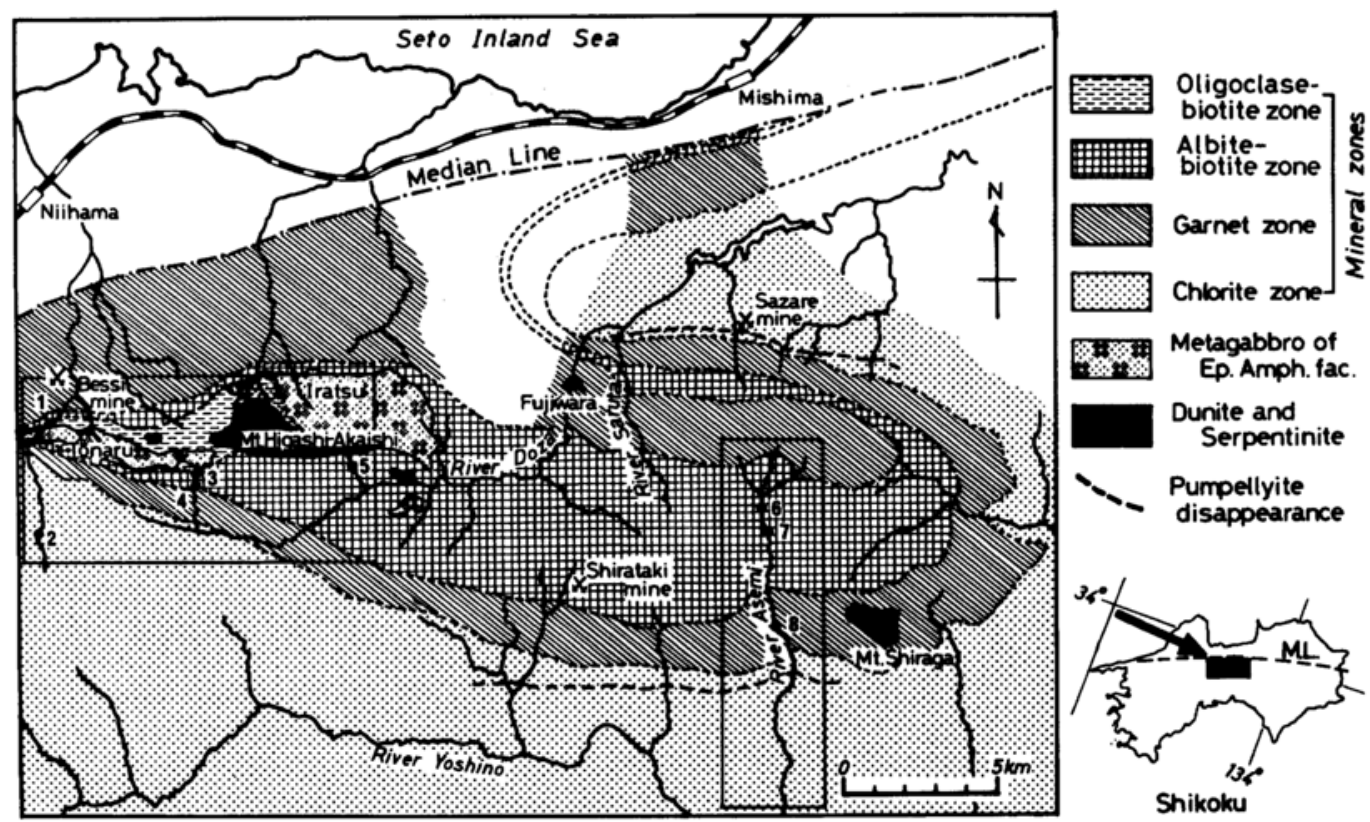

Fig. 1 Mineral zones of the Sanbagawa metamorphic terrain in central Shikoku after BANNO et al. (1978) and ENAMI (1981). Localities of samples studied for micro-probe analyses and study areas are shown by solid circles and rectangular outlines, respectively. 1: TOCPO1, 2: TH76052529, 3: CS82051808, 4: CS82051805, 5: TH75042834, 6: TH71081312, 7: TH71081422, 8: TH71080203.

zoisite. It can be easily identified, however, since a faint pleochroic halo develops around it (Figs. 2a, b), when included in chlorite and biotite. However, when included in quartz and sodic plagioclase, it is not accompanied by a pleochroic halo, and hence it can not be detected under the microscope. Thus, it was found that about 60 per cent (151 samples) of the pelitic schists from the chlorite to oligoclase-biotite zones contain REE-bearing epidote, but this value may be minimum because of the difficulty of identification. Eight samples from four mineral zones, which contain considerable amounts of REE-bearing epidote and allanite were studied with an electron micro-probe analyzer. REE-bearing epidote never forms porphyroblasts, and occurs in the matrix or enclosed in sodic plagioclase porphyroblasts that develop in the garnet, albite-biotite and oligoclase-biotite zones. Rarely, it is included in garnet, hornblende or tourmaline. In the oligoclase-biotite zone, some REE-bearing epidotes are included in zoisite.

Where REE-bearing epidote is euhedral, it is a slender prism with crystallographic b-axis parallel to the direction of tectonic b-axis (direction of mineral lineation) of the schists. Figure 3 shows the grain size (long diameter) distributions of REE-bearing epidotes in the randomly sampled pelitic schists from the chlorite to albite-biotite zones. REE-bearing epidotes were identified by the presence of pleochroic haloes, and hence their size distribution is of those included in chlorite and biotite. The size distributions are best approximated by Poisson distributions. The average grain size systematically increases: $31.0 \mu \mathrm{m}$ in the chlorite, $55.5 \mu \mathrm{m}$ in the garnet and $63.7 \mu \mathrm{m}$ in the albite-biotite zones, respectively, but kurtosis decreases in order of increasing metamorphic temperature. The size of REEbearing epidote is smaller than that of epidote which has no pleochroic halo in the host: its average size is $90 \mu \mathrm{m}$ in the chlorite, $100 \mu \mathrm{m}$ in the garnet and $135 \mu \mathrm{m}$ in the albite-biotite 
zones. The REE-bearing epidote is also smaller than zoisite ( $183 \mu \mathrm{m}$ on average).

Allanite also occurs in the pelitic schists from all metamorphic grades. It occurs mainly in muscovite-chlorite rich layer, but rarely in quartz-sodic plagioclase rich layers (Fig. 4). The axial colors of allanite are as follows: $\mathrm{X}=$ pale yellow orange - yellowish brown, $\mathrm{Y}=$ chestnut brown and $\mathrm{Z}=$ dark yellowish brown - chestnut brown. All of the allanites are in a non-metamict state; they are anhedral with outlines such as oval, triangular and square with caves or irregular undulations (Figs. $4 \mathrm{a}, \mathrm{b}$ ). The allanite is invariably filmed or surrounded with REE-bearing epidote and REE-free epidote
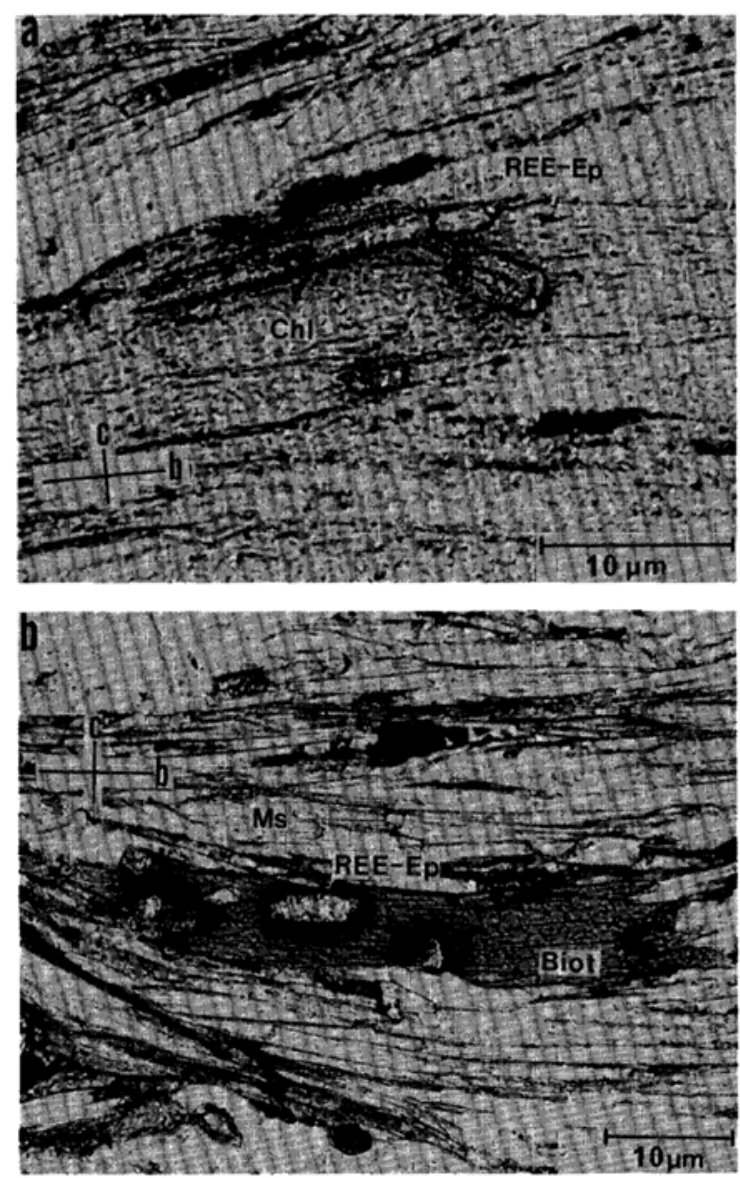

Fig. 2 Photomicrographs of REE-bearing epidotes included in chlorite and biotite. Fig. 2-a: Sample TH71081403, and Fig. 2-b: Sample TH71081305. REE-Ep: REE-bearing epidote, Ep: REE-free epidote, biotite, Ms: muscovite. The letters $b$ and $c$ show tectonic $b$-and c-axes, respectively. which are elongated parallel to the tectonic b-axis, but the morphological orientation of allanite is variable from grain to grain, and inconsistent with those of overgrown epidotes. Very often, a faint pleochroic halo develops in chlorite and biotite with which allanite is in contact (Fig. 4b). Sometimes, the boundary between allanite and overgrown epidotes is sharp, but sometimes it is not. Allanite and overgrown epidotes have several cracks in common. The amount of the overgrown epidotes increases with increasing metamorphic temperature.

Grain sizes of allanites were measured in schists ranging in grade from the garnet to the albite-biotite zones. The average grain size is nearly constant over this range of grade:
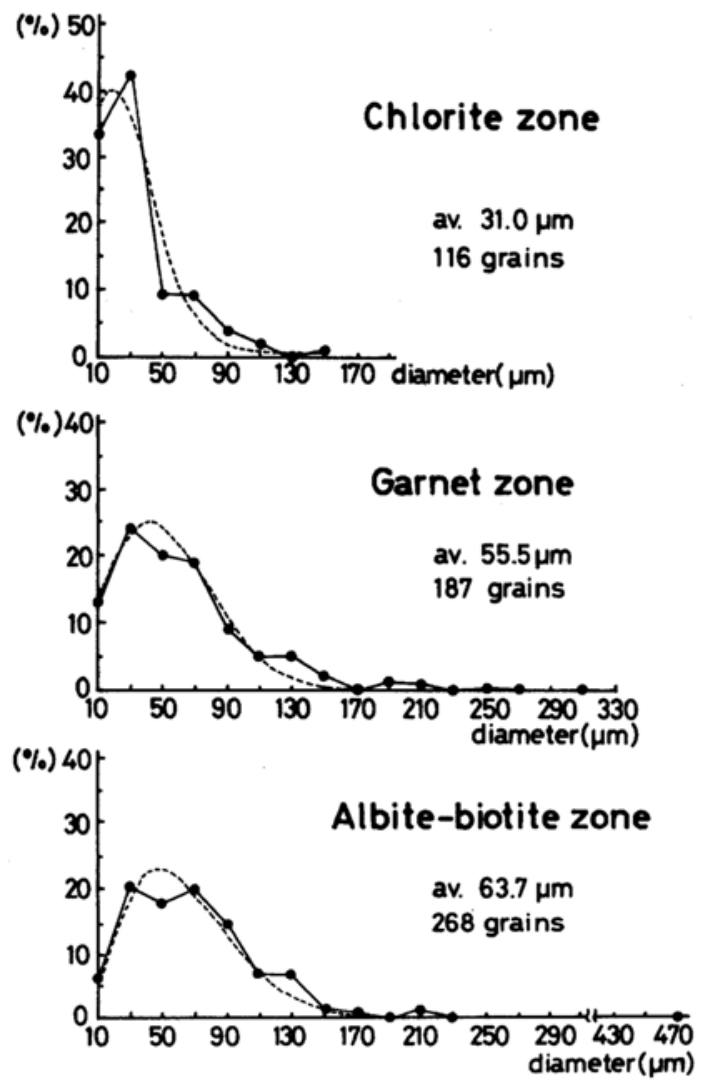

Fig. 3 Grain size (long diameter) distributions of REEbearing epidotes enclosed, or in contact with chlorite or biotite. Dashed lines are best-fitted Poisson distributions. 
$77 \mu \mathrm{m}$ (average value of 107 grains) in the garnet and $80 \mu \mathrm{m}$ (average value of 37 grains) in the albite-biotite zones, respectively.

\section{Analytical Procedure}

REE-bearing epidote and allanite were analyzed by means of an electron-probe microanalyzer with an energy dispersive analytical system (Kevex corporation EDS), attached with a scanning electron microscope (SEM), Hitachi S-550 of Kyoto University. All the analytical points were selected on the secondary electron image. Accelerating voltage was kept at $15.0 \mathrm{KV}$. The beam current was $3.0 \times 10^{-10} \mathrm{~A}$,
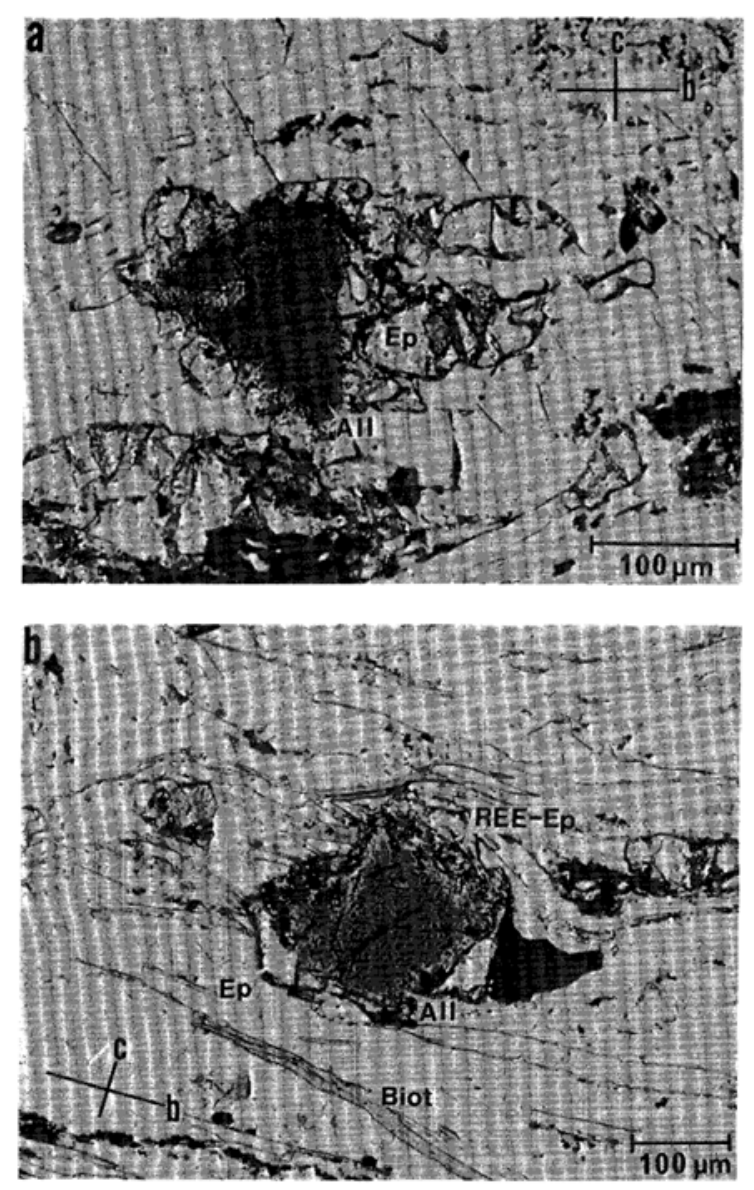

Fig. 4 Photomicrographs of allanites. (a) Sample CS82051808. (b) Sample TH71081422. All: allanite, REE-Ep: REE-bearing epidote, Ep: REE-free epidote, Biot: biotite. The letters $b$ and $c$ show tectonic $b$ - and c-axes, respectively. and beam diameter less than $1.0 \mu \mathrm{m}$. The ZAF scheme of Kevex Magic $V$ was used throughout. The standards are natural pyroxene for $\mathrm{Mg}$, natural epidote for $\mathrm{A} 1, \mathrm{Si}, \mathrm{Ca}$ and $\mathrm{Fe}$, synthetic rutile for $\mathrm{Ti}$, synthetic glasses of DRAKE and WeILl (1972) for REE (La, Ce, $\mathrm{Pr}, \mathrm{Nd}, \mathrm{Sm}$ and $\mathrm{Gd}$ ) and natural euxenite of SMELlIE et al. (1977) for Th. Microprobe analyses of REE-bearing epidote and allanite were done by using $\mathrm{K} \alpha$ lines for major elements, $\mathrm{L} \alpha$ lines for REE, and $\mathrm{M} \alpha$ lines for Th. The EDS has a resolving power of about $300 \mathrm{eV}$. Counting errors due to small contents of $\mathrm{Mg}$, $\mathrm{Ti}, \mathrm{REE}$ and $\mathrm{Th}$ were reduced by employing count times ranging from 400 to 800 seconds. Decrement of X-ray intensity was not detected regardless of the irradiation time. The analysis obtained by EDS was compared with that by wave dispersive analytical system (WDS: J.E.O L. JXA-50A of Kyoto University, accelerating voltage: $15.0 \mathrm{KV}$, specimen current: $2.0 \times$ $10^{-8} \mathrm{~A}$, counting time: 50 seconds). For the WDS, the correction parameter of BENCE and ALBEE (1968) was followed along with modification of the procedure given in YAMAGUCH i $e t$ al. (1978). The effects of intra-REE interferences, and $\operatorname{TiK} \beta_{1}$ and $\operatorname{LaL} \beta_{1}$ interferences on $\operatorname{PrL} \alpha_{1}$ were checked following ExLEY (1980), and then $\mathrm{L} \alpha$ peaks were selected for $\mathrm{La}, \mathrm{Ce}, \mathrm{Sm}$ and $\mathrm{Gd}$, and $\mathrm{L} \beta$ peaks for $\operatorname{Pr}$ and $\mathrm{Nd}$, respectively. The detection limits for the REE are less than 0.10 wt. per cent as oxide, throughout. Heavy rare earth elements (HREE: Yb, Dy, Ho, Er, $\mathrm{Tm}, \mathrm{Yb}$ and $\mathrm{Lu}$ ) and yttrium were not detected throughout, because of their low contents.

Table 1 shows the comparison between the chemical compositions of an allanite analyzed by EDS and those by WDS. The values obtained by EDS are the same as those by WDS within the statistic errors (2-sigma). The structural formula on the basis of $\mathrm{O}=12.5 \mathrm{fol}$ lows that of ideal allanite. Consequently, all the REE-bearing epidotes and allanites were analyzed by using EDS. 
Table 1. Chemical compositions and atomic ratios of allanite by EDS and WDS. Sample No. CS82051808. Each analysis is a 4 point average. $\mathrm{FeO}$ * means total iron as $\mathrm{FeO}$. The analyses were recalculated using the charge balance criterion of 8.0 cations per 12.5 negative charges to enable estimation of the amount of $\mathrm{Fe}^{3+} . \mathrm{R}^{3+}+\mathrm{R}^{2+}$ means $\mathrm{Ti}+\mathrm{Al}+$ $\mathrm{Fe}^{3+}+\mathrm{Fe}^{2+}+\mathrm{Mn}+\mathrm{Mg}$.

\begin{tabular}{lcccc} 
Oxides & EDS* & 2-sigma & WDS** & 2-sigma \\
\hline $\mathrm{SiO}_{2}$ & 31.13 & $(0.18)$ & 30.83 & $(0.58)$ \\
$\mathrm{TiO}_{2}$ & 1.21 & $(0.10)$ & 1.49 & $(0.08)$ \\
$\mathrm{Al}_{2} \mathrm{O}_{3}$ & 14.29 & $(0.14)$ & 14.45 & $(0.40)$ \\
$\mathrm{FeO}^{*}$ & 13.62 & $(0.16)$ & 13.55 & $(0.38)$ \\
$\mathrm{MnO}$ & n.d. & & 0.10 & $(0.02)$ \\
$\mathrm{MgO}$ & 0.40 & $(0.08)$ & 0.57 & $(0.04)$ \\
$\mathrm{CaO}$ & 9.55 & $(0.08)$ & 9.41 & $(0.26)$ \\
$\mathrm{ThO}_{2}$ & 1.03 & $(0.14)$ & $n . d$. & \\
$\mathrm{La}_{2} \mathrm{O}_{3}$ & 5.38 & $(0.40)$ & 5.75 & $(0.08)$ \\
$\mathrm{Ce}_{2} \mathrm{O}_{3}$ & 11.85 & $(0.98)$ & 11.69 & $(0.30)$ \\
$\mathrm{Pr}_{2} \mathrm{O}_{3}$ & 1.01 & $(0.32)$ & 1.16 & $(0.12)$ \\
$\mathrm{Nd}_{2} \mathrm{O}_{3}$ & 4.21 & $(0.31)$ & 3.58 & $(0.34)$ \\
$\mathrm{Sm}_{2} \mathrm{O}_{3}$ & 1.75 & $(0.28)$ & 1.52 & $(0.14)$ \\
$\mathrm{Gd}_{2} \mathrm{O}_{3}$ & 2.06 & $(0.34)$ & 1.69 & $(0.12)$ \\
\hline $\mathrm{Total}$ & 97.49 & & 95.79 &
\end{tabular}

Atomic ratios $(0=12.5)$

Cation total was normalized to 8.0

\begin{tabular}{lcl}
$\mathrm{Si}$ & 3.082 & 3.064 \\
$\mathrm{Ti}$ & 0.090 & 0.111 \\
$\mathrm{Al}$ & 1.667 & 1.692 \\
$\mathrm{Fe}^{3+}$ & 0.004 & 0.045 \\
$\mathrm{Fe}^{2+}$ & 1.124 & 1.081 \\
$\mathrm{Mn}$ & & 0.008 \\
$\mathrm{Mg}$ & 0.059 & 0.084 \\
$\mathrm{Ca}$ & 1.013 & 1.002 \\
$\mathrm{Th}$ & 0.023 & \\
$\mathrm{La}$ & 0.196 & 0.211 \\
$\mathrm{Ce}$ & 0.429 & 0.425 \\
$\mathrm{Pr}$ & 0.036 & 0.042 \\
$\mathrm{Nd}$ & 0.149 & 0.127 \\
$\mathrm{Sm}$ & 0.060 & 0.052 \\
$\mathrm{Gd}$ & 0.068 & 0.056 \\
\hline $\mathrm{Ca}+\mathrm{REE}+\mathrm{Th}$ & 1.974 & 1.915 \\
$\mathrm{R}^{3+}+\mathrm{R}^{2+}$ & 2.944 & 3.021 \\
\multicolumn{2}{c}{ n.d.: not } &
\end{tabular}

\section{Chemistry of Allanite AND ReE-BEARING EPIDOTE}

REE-bearing epidote contains REE totaling up to about 15 wt. per cent with $\mathrm{Ce}$ up to 7.1 wt. per cent as oxide at the maximum. $\mathrm{ThO}_{2}$ ranges from 0.5 to 1.0 wt. per cent (Table 2). REE-bearing epidote generally shows chemical zonation with regard to the major elements as well as REE and Th.

Figure 5 shows typical zonations of REEbearing epidotes. Sometimes, REE decrease outwards from the core, and $\mathrm{CaO}$ increases to balance the REE (Fig. 5a), but sometimes REE increase from the core to the rim being compensated by the decrement of $\mathrm{CaO}$ (Fig. 5b).

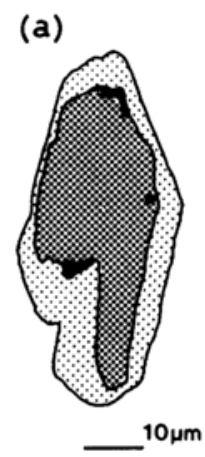

(b)

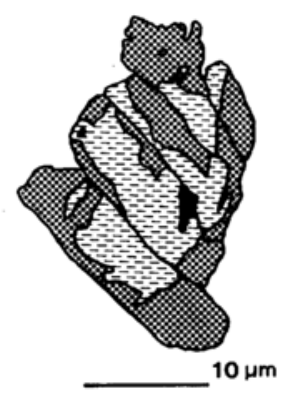

(c)

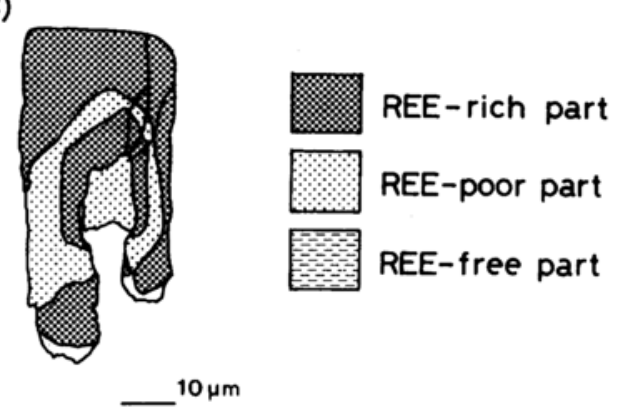

Fig. 5 Typical zonations of REE-bearing epidotes. (a) Sample TH75042834. Core contains a significant amount of $\mathrm{Ce}_{2} \mathrm{O}_{3}$ up to 6.2 wt. per cent. $\mathrm{Ce}_{2} \mathrm{O}_{3}$ content of the rim ranges from 1.1 to $2.3 \mathrm{wt}$. per cent. (b) Sample TH71081312. REE-rich rim contains $\mathrm{Ce}_{2} \mathrm{O}_{3}$ ranging from 3.6 to $5.4 \mathrm{wt}$. per cent. Core does not contain any REE. (c) Sample TH71081312. REErich part contains $\mathrm{Ce}_{2} \mathrm{O}_{3}$ ranging from 3.8 to $4.5 \mathrm{wt}$. per cent. $\mathrm{REE}$-poor part contains $\mathrm{Ce}_{2} \mathrm{O}_{3}$ up to 1.2 wt. per cent. 
Table 2. Chemical compositions and atomic ratios of REE-bearing epidotes, allanites and zoisite. $\mathrm{FeO} *$ means total iron as $\mathrm{FeO}$. The analyses except that of zoisite were recalculated using the charge balance criterion of 8.0 cations per 12.5 negative charges to enable estimation of the amount of $\mathrm{Fe}^{3+}$. Atomic ratios of zoisite is calculated on the basis of the $\mathrm{O}=12.5 . \mathrm{R}^{3+}+\mathrm{R}^{2+}$ means $\mathrm{Ti}+\mathrm{Al}+\mathrm{Fe}^{3+}+\mathrm{Fe}^{2+}+\mathrm{Mg}$.

\begin{tabular}{|c|c|c|c|c|c|c|}
\hline \multirow{2}{*}{$\begin{array}{l}\text { Minerals } \\
\text { Sample No. }\end{array}$} & \multicolumn{3}{|c|}{ REE-bearing epidote } & \multicolumn{2}{|c|}{ Allanite } & \multirow{3}{*}{$\begin{array}{c}\text { Zoisite } \\
\text { TOCP-01 } \\
\text { ZO2-2 }\end{array}$} \\
\hline & TH71081312 & TH75042834 & TOCP-01 & TH76042529 & CS82051808 & \\
\hline Grain No. & REE3-3 & REE1-1 & REE1-1 & ALN1-1 & ALN1-1 & \\
\hline $\mathrm{SiO}_{2}$ & 37.17 & 35.33 & 35.60 & 30.49 & 31.15 & 39.50 \\
\hline $\mathrm{TiO}_{2}$ & n.d. & n.d. & n.d. & 1.73 & 1.23 & \\
\hline $\mathrm{Al}_{2} \mathrm{O}_{3}$ & 25.36 & 23.04 & 24.55 & 13.82 & 14.34 & 33.53 \\
\hline $\mathrm{FeO}^{*}$ & 7.86 & 8.94 & 8.87 & 14.42 & 13.14 & 1.31 \\
\hline $\mathrm{MgO}$ & 0.67 & 0.37 & n.d. & 0.42 & 0.43 & \\
\hline $\mathrm{CaO}$ & 18.87 & 16.50 & 16.05 & 9.74 & 9.42 & 24.82 \\
\hline $\mathrm{ThO}_{2}$ & 0.44 & 1.01 & n.d. & n.d. & 1.31 & \\
\hline $\mathrm{La}_{2} \mathrm{O}_{3}$ & 1.50 & 2.00 & 3.21 & 6.36 & 5.41 & \\
\hline $\mathrm{Ce}_{2} \mathrm{O}_{3}$ & 3.83 & 4.79 & 7.05 & 11.63 & 11.72 & \\
\hline $\mathrm{Pr}_{2} \mathrm{O}_{3}$ & 0.25 & 0.36 & n.d. & 1.31 & 0.97 & \\
\hline $\mathrm{Nd}_{2} \mathrm{O}_{3}$ & 1.38 & 1.62 & 1.55 & 3.59 & 4.07 & \\
\hline $\mathrm{Sm}_{2} \mathrm{O}_{3}$ & 1.33 & 0.97 & 1.70 & 1.81 & 2.44 & \\
\hline $\mathrm{Gd}_{2} \mathrm{O}_{3}$ & 0.15 & 0.57 & 1.38 & 2.11 & 1.48 & \\
\hline Total & 98.81 & 95.50 & 99.96 & 97.43 & 97.11 & 99.16 \\
\hline $\mathrm{REE}_{2} \mathrm{O}_{3}+\mathrm{ThO}_{2}$ & 8.88 & 11.32 & 14.89 & 26.81 & 27.04 & \\
\hline At & mic ratios of RE & -bearing epidot & $\begin{array}{l}\text { ind allanites } \\
\text { ept for zois }\end{array}$ & & & \\
\hline $\mathrm{Si}$ & 3.035 & 3.068 & 3.014 & 3.016 & 3.099 & 2.966 \\
\hline $\mathrm{Ti}$ & & & & 0.129 & 0.092 & \\
\hline $\mathrm{Al}_{3+}$ & 2.440 & 2.358 & 2.449 & 1.611 & 1.681 & 2.966 \\
\hline $\mathrm{Fe}^{3+}$ & 0.225 & 0.143 & 0.069 & 0.142 & 0.000 & 0.082 \\
\hline $\mathrm{Fe}^{2+}$ & 0.312 & 0.506 & 0.559 & 1.051 & 1.153 & \\
\hline $\mathrm{Mg}$ & 0.082 & 0.048 & & 0.062 & 0.064 & \\
\hline $\mathrm{Ca}$ & 1.650 & 1.534 & 1.455 & 1.032 & 1.004 & 1.996 \\
\hline Th & 0.008 & 0.020 & & & 0.030 & \\
\hline $\mathrm{La}$ & 0.045 & 0.064 & 0.100 & 0.232 & 0.198 & \\
\hline $\mathrm{Ce}$ & 0.114 & 0.152 & 0.218 & 0.421 & 0.427 & \\
\hline Pr & 0.007 & 0.011 & & 0.047 & 0.035 & \\
\hline $\mathrm{Nd}$ & 0.040 & 0.050 & 0.047 & 0.127 & 0.145 & \\
\hline $\mathrm{Sm}$ & 0.037 & 0.029 & 0.050 & 0.062 & 0.084 & \\
\hline Gd & 0.004 & 0.016 & 0.039 & 0.069 & 0.049 & \\
\hline Total & & & & & & 8.010 \\
\hline $\mathrm{Ca}+\mathrm{REE}+\mathrm{Th}$ & 1.905 & 1.876 & 1.909 & 1.990 & 1.972 & \\
\hline $\mathrm{R}^{3+}+\mathrm{R}^{2+}$ & 3.059 & 3.055 & 3.077 & 2.995 & 2.990 & \\
\hline
\end{tabular}

Further, some epidotes show complex chemical zonation for $\mathrm{CaO}$, and $\mathrm{REE}$ (Fig. 5c). There is no relationship between the types of zonations of REE-bearing epidote and metamorphic grade. Some large grains of epidote, which are included in chlorite and biotite and form no pleochroic halo around them, contain REE and Th-rich core (Fig. 6). None of the zoisites contain REE and Th (Table 2).

Allanite contains significant amounts of REE totaling up to about 26 wt. per cent with Ce up to 11.7 wt. per cent as oxide. It also 
contains $\mathrm{ThO}_{2}$ up to 1.3 wt. per cent (Table 2). The amounts of $\mathrm{Al}_{2} \mathrm{O}_{3}, \mathrm{CaO}$ and $\mathrm{Fe}_{2} \mathrm{O}_{3}$ as well as REE and Th are not so much variable not only within a grain, but also in all the pelitic schists regardless of the metamorphic grade.

The boundary between allanite and overgrown clinozoisite is generally sharp (Fig. 7a), but some allanites have a diffusion induced concentration gradient near the interfaces with clinozoisite (Fig. 7b).

Figure 8 shows the relationship among REE, $\mathrm{Ca}, \mathrm{Fe}^{2+}, \mathrm{Fe}^{3+}+\mathrm{Al}$ in the REE-bearing epidote. $\mathrm{Fe}^{2+}$ and $\mathrm{Fe}^{3+}$ were recalculated from total $\mathrm{Fe}$ assuming following stoichiometry (Ca REE, Th) $)_{2}\left(\mathrm{Al}, \mathrm{Fe}^{3+}, \mathrm{Fe}^{2+}\right)_{3} \mathrm{Si}_{3} \mathrm{O}_{12}(\mathrm{OH})$. The clear correlation between $\mathrm{Fe}^{2+}$ and total REE in Fig. 8 supports this procedure. With increasing $\mathrm{REE}$, the concentrations of $\mathrm{Ca}$ and $\mathrm{Fe}^{3+}+\mathrm{Al}$ decrease and that of $\mathrm{Fe}^{2+}$ increases,

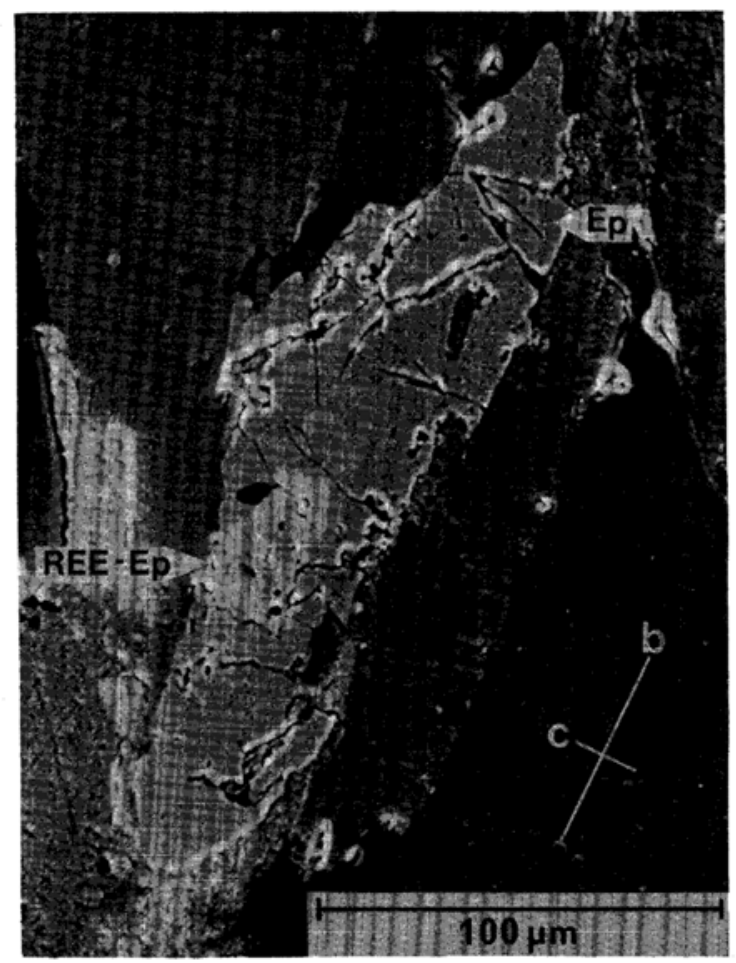

Fig. 6 Secondary electron image of a large grain of epidote in the matrix. Sample CS82051805; Light part is $R E E$ and Th-bearing core, and dark part is REE and Th-free. $R E E$-Ep: $R E E$-bearing core, Ep: REE-free part. The letters $b$ and $c$ show tectonic $b$-and c-axes, respectively.
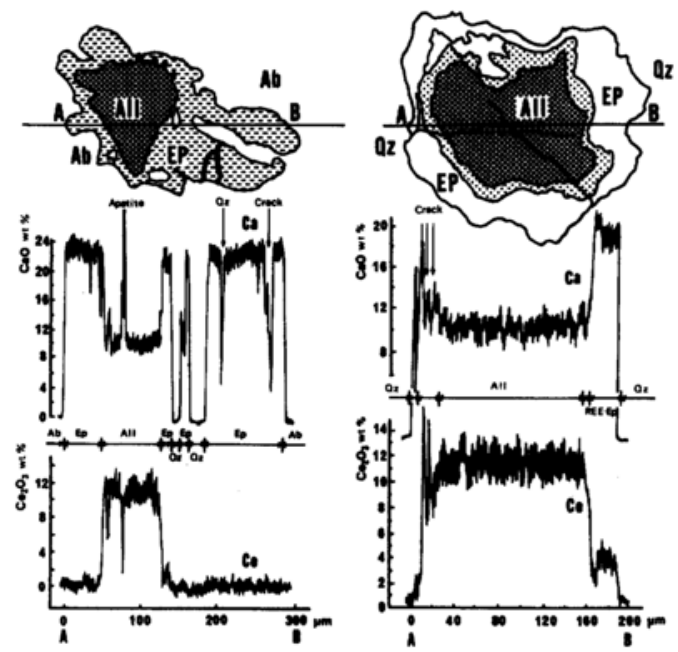

Fig. 7 Chemical profiles of allanites surrounded with $R E E$-free and -bearing epidotes for $\mathrm{CaO}$ and $\mathrm{Ce}_{2} \mathrm{O}_{3}$. (a) Sample CS82051805 and (b) Sample TH71081422. Photomicrographs of these allanites are shown in Fig. 4. All: allanite, Ep: REE-free epidote, Ab: albite, $Q z$ : quartz.

suggesting the major substitution of $\mathrm{Ca}^{2+}\left(\mathrm{Fe}^{3+}\right.$, Al) by $\mathrm{REE}^{3+} \mathrm{Fe}^{2+}$ in the REE-bearing epidotes.

Figure 9 shows the chondrite normalized REE-patterns of allanite and REE-bearing epidote. The REE abundances are normalized to the values in Leedey chondrite (L6) of MASUDA et al. (1973). The chondrite normalized REE patterns of allanite are conspicuously different from those of allanite reported by EXLEY (1980) and HARDING et al. (1982). Allanite and REE-bearing epidote have rather similar patterns of REE enrichment, such that light REE are enriched although details differ between them. The overall similarity of the chondrite normalized REE-pattern between them suggests that allanite is the major source of REE of the pelitic schists.

\section{Discussion}

REE-bearing epidote was formed during the Sanbagawa metamorphism as evidenced by the following: (1) The average grain size of REE-bearing epidote systematically increases with increasing metamorphic grade. (2) Slender, 


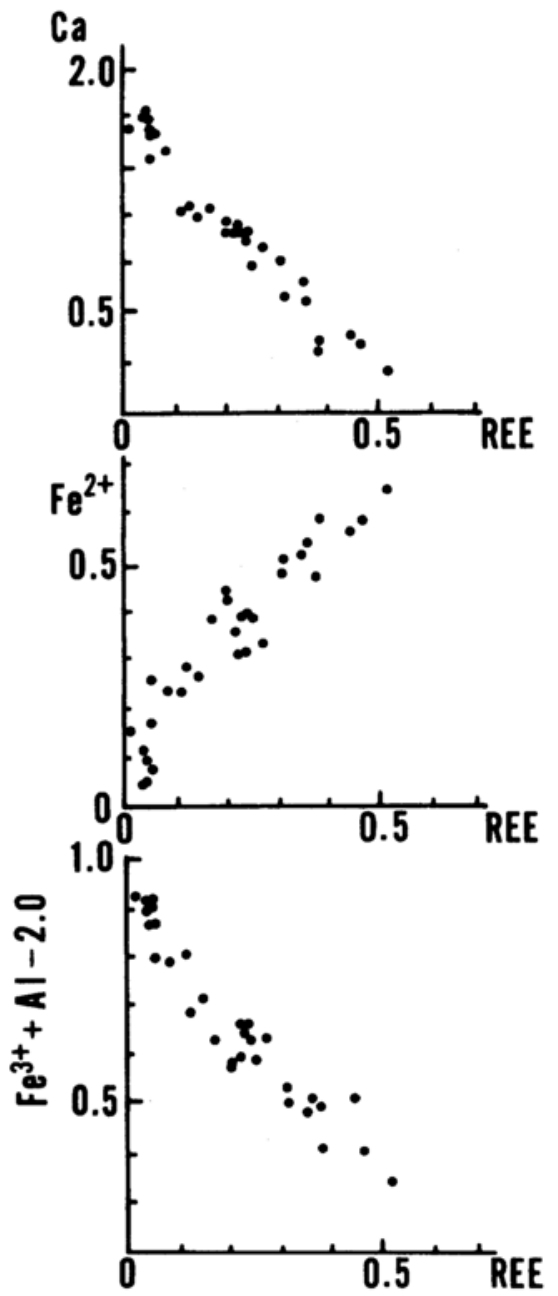

Fig. 8 Relationship among $\mathrm{REE}, \mathrm{Ca}, \mathrm{Fe}^{2+}$, and $\left(\mathrm{Fe}^{3+}+\mathrm{Al}\right)$ in the REE-bearing epidote.

prismatic euhedral crystals have their crystallographical b-axis parallel to the direction of tectonic b-axis of the host schists. (3) The amount of the overgrown REE-bearing epidote increases with increasing temperature. Allanite, however, is detrital as revealed by the following: (1) Absence of any relationship between the grain size and metamorphic grade, and (2) anhedral shape with irregular outlines.

REE and Th have not been detected as yet in hornblende, sphene and apatite by the micro-probe. Therefore, epidote is the only metamorphic mineral which contains significant amounts of REE and Th in the pelitic schists.

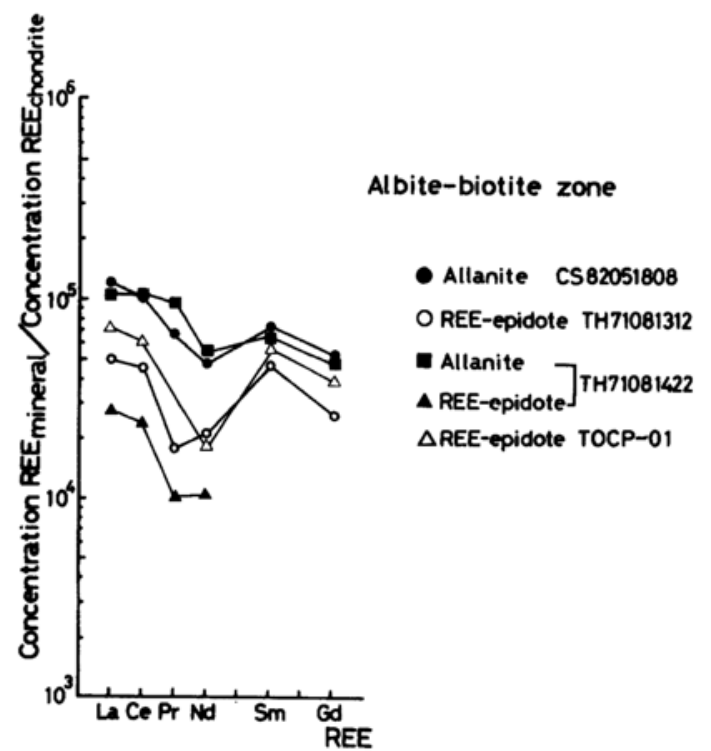

Fig. 9 Chondrite normalized REE-patterns for detrital allanites and REE-bearing epidotes.

The chondrite normalized REE-patterns of the REE-bearing epidote and detrital allanite suggest that the allanite is the major source of REE of the pelitic schists.

REE and Th fixed in epidote were transported from the detrital allanite by the metamorphic fluid. The amount of REE and Th in the fluid changed in a host rock from place to place during the metamorphism, probably because the formation of epidote armor around the detrital allanite prevented its rapid dissolution into the fluid, but allowed to supply small amounts of REE during the whole span of lowto medium-grade metamorphism. Variety of chemical zonations of REE-bearing epidotes is due to the fluctuation of REE and Th fluxes into the metamorphic fluid. Some large grains of epidotes contain REE and Th-rich core, but REE-free rim (Fig. 6). This implies that the formation of epidote armor around the detrital allanite effectively prevented the REE dissolution into the fluid. In low- to medium-grade metamorphism, REE do not move homogeneously in the host rock and their distribution is heterogeneous owing to the chemical kinetics between the REE dissolution into the meta- 
morphic fluid and growth of epidotes during the prograde metamorphism.

Acknowledgements-The authors would like to express their sincere thanks to Prof. S. BANNO of Kyoto University, for the critical reading of this manuscript as well as his constructive critisms and stimulating discussions. Prof. E. H. BROWN of W. Washington University is thanked for his discussion on the scientific and linguistic aspect of this paper. Their thanks are due to Mr. A. TAKASU of Kyoto University, for WDS analyses of allanite, and to Prof. D. F. WEILL of Oregon University who generously provided the standards for REE.

\section{REFERENCES}

BANNO, S. (1964) Petrologic studies on Sanbagawa crystalline schists in the Bessi-Ino district, central Shikoku, Japan. J. Fac. Sci. Univ. Tokyo Ser. II 15, 203-319.

BanNo, S., Higashino, T., OTSUKi, M., Itaya, T. and NAKAJIMA, T. (1978) Thermal structure of the Sanbagawa metamorphic belt in central Shikoku. J. Phys. Earth 26, Suppl. 345-356.

BENCE, A.E. and ALBEE, A.L. (1968) Empirical correction factors for electron microanalyses of silicates and oxides. J. Geol. 76, 382-403.

DEER, W.A., HOWIE, R.A. and ZUSSMAN, J.Z. (1962) Ortho- and ring silicates, An introduction to the rock-forming minerals. Vol. 1. in Longmans.

DRAKE, M.J. and WEILL, D.F. (1972) New rare earth element standards for electron microprobe analysis. Chem. Geol. 10, 179-181.

ENAMI, M. (1981) On sodic plagioclase in some rocks of the Sanbagawa metamorphic belt in the Bessi district, Shikoku, Japan. Proc. Jap. Acad. 57, Ser. B, 188-193.

ENAMI, M. (1982) Oligoclase-biotite zone of the Sanbagawa metamorphic terrain in the Bessi district, central Shikoku, Japan. J. Geol. Soc. Japan. 88, 887-900 (in Japanese with English abstract).

EnAMI, M. (1983) Petrology of pelitic schists in the oligoclase-biotite zone of the Sanbagawa metamorphic terrain, Japan: phase equilibria in the highest grade zone of a high-pressure intermediate type of metamorphic belt. J. Metamorphic Geol., 1, 141161.
EXLEY, R.A. (1980) Microprobe studies of REE-rich accessory minerals for Skye granite petrogenesis and REE mobility in hydrothermal systems. Earth Planet. Sci. Lett. 48, 97-110.

HARDING, R.R., MERRIMAN, R.J. and NANCARROW, P.H.A. (1982) A note on the occurrence of chevkinite, allanite, and zirkelite on St. Kilda, Scotland. Mineral. Mag. 46, 445-448.

HASEGAWA, S. (1960) Chemical composition of allanite. Sci. Rep. Tohoku Univ., Ser. III, 6, 331387.

HIDE, K. (1961) Geologic structure and metamorphism of the Sambagawa crystalline schists of the Besshi-Shirataki mining district in Shikoku, southwest Japan. Geol. Rep. Hiroshima Univ. 9, 87p. (in Japanese with English abstract).

Higashino, T. (1975) Biotite zone of Sanbagawa metamorphic terrain in the Shiragayama area, central Shikoku, Japan. J. Geol. Soc. Japan. 81, 653-670 (in Japanese with English abstract).

HORIKOSHI, Y. (1938) On minerals in metamorphic rocks from the vicinity of Besshi, Shikoku: part 2 epidote group. J. Geol. Soc. Japan. 45, 342-351 (in Japanese).

ITAYA, T. (1981) Carbonaceous material in pelitic schists of the Sanbagawa metamorphic belt in central Shikoku, Japan. Lithos 14, 215-224.

KoIDE, H. (1937) Geological and petrological study on the forest site. (II) On the crystalline schist of Sambagawa series as the bed rocks of Sugi-forest in the lower Tenryu district. Bull. Tokyo Univ. Forest 24, 76p. (in Japanese).

MASUda, A., NAKamURA, N. and TANAKa, T. (1973) Fine structures of mutually normalized rare-earth patterns of chondrites. Geochim. Cosmochim. Acta 37, 239-248.

Smellie, J.A.T., Cogger, N. and Herrington, J. (1977) Standards for quantitative microprobe determination of uranium and thorium with additional information on the chemical formulae of davidite and euxenite-polycras. Chem. Geol. 22, $1-10$.

SUZUKI, J. (1930) Petrological study of the crystalline schist system of Shikoku, Japan. J. Fac. Sci., Hokkaido Imp. Univ. Ser. IV 1, 27-111.

YAMAGUCHI, Y., AKAI, J. and TOMITA, K. (1978) Clinopyroxene lamellae in diopside of garnet lherzolite from Alpe Arami, Bellinzona, Swizerland. Contrib. Mineral. Petrol. 66, 263-270. 